\title{
Thinking about Intelligence Within, Without, and Beyond the State*
}

\author{
Peter Gill \\ University of Liverpool, UK
}

\section{Introduction}

The reform or 'democratization' of intelligence has been studied in many countries essentially as a process of transition from authoritarian or 'counterintelligence' states to liberal democratic regimes in which security and intelligence agencies are subject to (more or less) democratic control and oversight. ${ }^{1}$ These studies have contributed to the growth in comparative studies of intelligence but have often ignored some key issues, including the conditions for the very existence of 'state' intelligence, the continuing significance of parallel non-state intelligence entities and the involvement of an increasing number of corporate actors in intelligence activities. This chapter examines intelligence as it works within and between different 'sectors' and the implications for democratization.

Intelligence is a sub-set of 'surveillance', a ubiquitous social activity, and can be defined as: 'mainly secret activities - targeting, collection, analysis, dissemination and action - intended to enhance security and/or maintain power relative to competitors by forewarning of threats and opportunities. ${ }^{2}$ A central element of this definition - as with surveillance more generally is the link between information/knowledge and action/power (or, 'intelligence' and 'policy') ${ }^{3}$ where the objective of the process is security and it will be subject to resistance. Intelligence is exercised at various social 'levels' from the transnational to the personal: even individuals deploy information gathering in the face of uncertainty in order to assess threats etc.

\section{Sectors of Intelligence}

All the major contributing disciplines within intelligence studies have focused on the state. The study of war and the role of military intelligence have focused, until recently, on interstate violence and the archives providing the source for much of this study are themselves maintained and then released by states. Students of internal security intelligence have been concerned with the impact of political police on the rights and liberties of citizens and the study of criminal intelligence has focused similarly on the activities of public police forces. The examination of democratization has very naturally followed these paths in emphasizing

\footnotetext{
Peter Gill, Honorary Senior Research Fellow, University of Liverpool, UK. Email: p.gill@liv.ac.uk.

* This article was originally presented to the International Intelligence Symposium, Istanbul, in September, 2010. An alternative version is published as 'The Implications of Intelligence Practice Within and Beyond the State: An Analytical Model' in the Journal of Regional Security 8, no.2 (2013): 93-114, Belgrade: Belgrade Centre for Security Policy.

1 E.g. Thomas Bruneau and Steven Boraz, Reforming Intelligence: obstacles to democratic control and effectiveness (Austin: University of Texas Press, 2007); Stuart Farson, Peter Gill, Mark Phythian and Shlomo Shpiro, PSI Handbook of Global Security and Intelligence, National Approaches (Westport, CT: Praeger Security International, 2008).

2 Peter Gill, "Theories of Intelligence: where are we, where should we go and how might we proceed?" in Intelligence Theory: key questions and debates, ed. Peter Gill, Stephen Marrin and Mark Phythian (London: Routledge, 2009), 208-26.

3 c.f. Len Scott and Peter Jackson, "The Study of Intelligence in Theory and Practice," Intelligence and National Security 19, no.2 (2004): 150
} 
the legal and institutional aspects of intelligence. ${ }^{4}$ While this work has achieved much in clarifying the conditions under which intelligence may move from a repressive to a progressive political instrument, we must acknowledge the significance of two other intelligence sectors: corporate and 'sovereignties'.

There are a number of perspectives on the significance of the corporate sector. There is a long history of 'competitive' or 'business' intelligence in which firms gather information in relation to potential markets, activities of competitors and so on. ${ }^{5}$ Most of this is concerned with nothing more than the profitability of the firm's own products or services, is normally gathered from open sources and, as such, is quite different from the central concern of state's and their security intelligence. However, it would be better to see business intelligence on a continuum with state intelligence rather than as qualitatively different. At times these will shade into one another, for example, where the transnational activities of corporations have implications not only for their health but also for state policy in terms of alliances and trade. This is especially the case with defense industries where states are the only (legal) market that exists.

Second, there are those companies for whom security intelligence is central to their own operations and profitability. These are often discussed as either private military or private security companies (PMCs, PSCs). A number of factors have accounted for their significant growth in the last twenty years since the end of the Cold War. This led to a 'downsizing' of western security and intelligence agencies and thus a potential supply of experienced and skilled intelligence personnel while many smaller states lost the support of their former Cold War sponsors. Therefore, lacking their own state personnel, when they required expertise they turned to the corporate sector. ${ }^{6}$ Even the United States found itself, in the wake of 9/11, dependent on many former personnel, some recalled from retirement, some now employed in the private sector who became contractors. This process reached its height in Iraq and Afghanistan. Security contracting covers a multitude of roles from the purely logistical to involvement in fighting and requires intelligence support. Some have become highly controversial, however, none more than the involvement of contractors in interrogation at Abu Ghraib and actions of Blackwater (now Xe) operatives. ${ }^{7}$ In the context of continuing restrictions on state budgets, ever-increasing corporate competition for trade and resources and continuing security concerns in so many places, a significant corporate role is clearly going to continue.

But there is a third sector of intelligence; indeed, one that existed prior to the modern state and continues to be highly significant in many areas. This is manifested in numerous ways with varying degrees of organizational formality: national liberation movements, paramilitary groups, clan, tribal or religious militias, criminal organizations. What these 'para-states', or non-state 'sovereignties', have in common is their willingness to use violence to control people, resources, or territory ${ }^{8}$ or, as the UN Guidelines on Humanitarian

\footnotetext{
4 Hans Born and Ian Leigh, Making Intelligence Accountable: legal standards and best practice for oversight of intelligence agencies (Oslo: Publishing House of Parliament of Norway, 2005); Bruneau and Boraz, Reforming Intelligence.

5 Larry Kahaner, Competitive Intelligence: how to gather, analyze, and use information to move your business to the top (New York: Touchstone, 1996); Seena Sharp, Competitive Intelligence Advantage: how to minimize risk, avoid surprises and grow your business in a changing world (Hoboken, NJ: John Wiley and Sons, 2009).

6 E.g. Deborah Avant, The Market for Force: the consequences of privatizing security (Cambridge: Cambridge UP, 2005); Peter Singer, Corporate Warriors: the rise of the privatized military industry (Ithaca: Cornell University Press, 2003).

7 Jeremy Scahill, Blackwater: the rise of the world's most powerful mercenary army (London: Serpent's tail, 2007).

8 Michael Warner, "Intelligence as Risk Shifting," in Intelligence Theory: key questions and debates, ed. Gill, et al. (London: 
Negotiations describe them, non-state armed groups whose motives may be political, ideological or economic. ${ }^{9}$ Their activities are very similar to those of states although their legality may be highly contested. In some cases they will be clearly 'illegal' but there are some social organizations whose 'intelligence' activities will be conducted, as it were, on 'license' by states. 'Neighborhood watch' schemes, for example, are encouraged by police as complementary to community policing but if their members use violence - vigilantism - that will be officially discouraged even if sometimes a 'blind eye' is turned by state officials when the violence is compatible with state objectives.

But beyond the simple existence of these intelligence sectors, the relationships between them may be highly significant. In some cases there will be overlaps where actors within different sectors share tasks such as protective security but these will not always be obvious, for example, the same people may, at different times, act on behalf (or in the interests) of a state, a company or sovereignty. An especially lethal example of this would be 'death squads' made up of security or police personnel when 'off duty'. ${ }^{10}$

In other cases, the relationship will be more of a network governed by a series of more of less formal contractual relationships. Such co-operation has a long history; the best known formal agreement was the UKUSA treaty between US, UK, Canada, Australia and New Zealand to share SIGINT at the start of the Cold War. ${ }^{11}$ However, since 9/11 much effort has been put into improving the reach and intensity of intelligence networks - the basis for effective information sharing - not only in the United States, where the failure of agencies to share information was one finding of the 9/11 Commission, but between agencies in different states, including some whose historical relations had been competitive rather than cooperative.

Generally, the relationship between agencies or sectors will be one of conflict rather than cooperation where state, corporation or para-state target each other as perceived threats. Over time, any particular relationship may shift between these types. Documentation in relation to the state sector is far more extensive than for the other sectors so we can quickly identify examples of various state/corporate and state/para-state connections. The former includes most technological issues in current intelligence since state procurement is now primarily from the private sector where most hardware and software innovation takes place. In this and other high technology and defense areas, 'protective security' advice and its link with counterintelligence is another key connection and, for the US intelligence community, there has been much outsourcing of core intelligence work since 9/11, discussed further below. The interchange of personnel is also significant: those trained in intelligence and with specialist expertise will almost certainly be able to command greater salaries in the private sector, while those retiring from the public sector may seek to augment their pension with a corporate position. Often, just as significant as the acquisition of expertise is the ability to make use of former contacts in developing informal networks - the lifeblood of any 'intelligence' system. However, there may be more tension in these relations: formally the government of Nigeria cooperates with Shell Oil's extraction in the Niger Delta but, in the face of political support in the area for the ethnic militias opposing Shell, the company has employed various techniques,

9 Jeffrey Norwitz, Pirates, Terrorists, and Warlords: the history, influence, and future of armed groups around the world (New York: Skyhorse Publishing, 2009), 457.

${ }^{10}$ Bruce Campbell and Arthur Brenner ed., Death Squads in Global Perspective: murder with deniability (Basingstoke: Macmillan, 2000).

11 Jeffrey Richelson andc Desmond Ball, The Ties that Bind, 2nd ed., (Boston: Unwin Hyman, 1990). 
including penetrating the government with people seconded to relevant ministries (or so it claimed according to a US embassy cable from 2009 recently released by Wikileaks and bribery. ${ }^{12}$

While there are plenty of opportunities for profiteering and improper influence in legal state/corporate relations, cooperation between states and para-states is even more prone to corruption. In practice, even if lawful, these relations will be 'plausibly denied'. Prominent examples would include the CIA's Operation Mongoose to recruit the Mafia to assassinate Fidel Castro after the Bay of Pigs invasion failed to overthrow his government. ${ }^{13}$ Several plans, from exploding cigars to diving suits impregnated with poison failed, as is evident from Castro's longevity. In Northern Ireland there is strong evidence of 'collusion' between UK security forces (army, police and Security Service) that resulted in the killing of a number of alleged Republicans by the Loyalist paramilitary group, the Ulster Volunteer Force. ${ }^{14}$ More recently, in Iraq, the apparent success of the US surge in reducing the levels of violence in Iraq in 2007 was widely accredited to the mobilization of the Sons of Iraq to fight against al-Qaeda instead of supporting their insurgency. ${ }^{15} \mathrm{UK}$ forces in Basra sought to maintain peace similarly by co-operating with the Mahdi army. In Turkey, voluntary village guards have been deployed since the mid-1980s; they are unpaid but armed by the state in response to a local request for self-protection but their role has been highly controversial including involvement in murder, kidnapping, burning villages and torture. Recruited on the pretext of countering the PKK, they have been involved in arms and drugs trafficking may amount to little more than a security force for local clan chiefs. ${ }^{16}$

On the other hand, state contacts with non-state groups may involve the sharing of information as part of conflict-resolution and peace-keeping. ${ }^{17}$ During the 'Troubles' in Northern Ireland, there were systematic contacts between members of the SIS and PIRA through intermediaries which, eventually, contributed to the start of the formal 'peace process' in 1994. Similarly, the CIA has been a central player in Middle East peace negotiations. ${ }^{18}$ The efforts may or may not be successful but, from the point of view of governments who refuse to be seen 'talking to terrorists', intelligence services provide what is often the only possibility for backchannel negotiations. Success in these negotiations or some form of regime change may then give rise to the intriguing prospect of incorporating intelligence operatives from an insurgent group into a reformed state service. South Africa provides an excellent example of this from 1992 onwards $^{19}$ and a similar conundrum faces the construction of a new intelligence service in Kosovo. The other side of this issue is that if intelligence agents

\footnotetext{
12 Rowena Mason and Richard Blackden, "Shell to pay \$48m Nigrian bribe fine," The Telegraph, November 4, 2010; "Shell Md Discusses the Status of the Proposed Petroleum," Wikileaks, http://wikileaks.ch/cable/2009/10/09ABUJA1907.html.

13 E.g. John Ranelagh, The Agency: the rise and decline of the CIA (New York: Simonand Schuster, 1987), 385-390.

14 Peter Gill, "Inquiring into Dirty Wars: a "huge smokescreen of humbug"?" in Commissions of Inquiry and National Security, ed. Stuart Farson and Mark Phythian (Santa Barbara: ABC-Clio, 2011).

15 "Awakening Movement in Iraq", New York Times, December 21, 2010, http://topics.nytimes.com/top/news/international/ countriesandterritories/iraq/awakening_movement/index.html.

16 Dilek Kurban, "The Village Guard System as a "Security" Policy", in Security Sector and Democratic Oversight, ed. Ali Bayramoğlu and Ahmet Insel (Istanbul: TESEV, 2010), 203-10.

17 E.g. Ben de Jong, Wies Platje and Robert Steele, Peacekeeping Intelligence: emerging concepts for the future (Oakton, VA: OSS International, 2003)

18 Shlomo Shpiro, "Intelligence, peacekeeping and Peacemaking in the Middle East," in Peacekeeping Intelligence: emerging concepts for the future, ed. de Jong et al. (Oakton, VA: OSS International, 2003), 101-14.

19 E.g. Kenneth Dombrowski, "Transforming Intelligence in South Africa," in Reforming Intelligence: obstacles to democratic control and effectiveness, ed. Thomas Bruneau and Steven Boraz, (Austin: University of Texas Press, 2007), 241-68; Kevin O'Brien, "South Africa," in PSI Handbook of Global Security and Intelligence, National Approaches, volume 2, ed. Stuart Farson et al, 
are removed from office by some process of lustration and feel themselves aggrieved or without an adequate pension, then they may rapidly find employment with either a corporate or illegal organization where they are able to deploy their skills and contacts.

Least documented are the links between para-states and the corporate sector. These are most likely to be significant in areas where the state itself lacks capacity, so, if a corporation contemplates activities there it may have to rely for information and some measure of security on a locally-based group.

\section{An Intelligence Monopoly?}

How to conceptualize intelligence as it operates in all sectors so as to deepen our understanding of democratization? It is suggested that the starting point will be the definition of intelligence, as given at the start of the article, which relates knowledge to power and sees intelligence as a sub-set of surveillance. We start with this functional view of intelligence but if we are to examine democratic forms then we need to be able to see where 'institutions' may fit. In the classic Weberian definition, what distinguishes states from other groups deploying violence is their 'monopoly of legitimate physical violence within a certain territory. ${ }^{20}$ In terms of considering what does constitute democratic intelligence, this is a key element but it is not the only one because violence is not the only form of power deployed as the outcome of some intelligence process. As a shorthand, we might add Etzioni's other two categories: utilitarian (material) and normative (symbolic). ${ }^{21}$ Obviously states use a variety of forms of power - in democratic states, coercion is seen as a last resort - but it is the capacity for deploying legitimate force that is the defining characteristic. Equally, however, Warner defines 'sovereignties' by 'their competitive willingness to use violence to hold or gain control over people, resources, and territory. ${ }^{22}$ But they cannot be defined solely in terms of the use of coercion; what is of empirical interest to students of intelligence is the way in which both states and non-states deploy intelligence in order to exercise power in all its forms, not just coercion.

When it comes to the more normative question of what constitutes democratic intelligence, can we develop anything as useful as the Weberian definition of 'state' based on the monopoly of legitimate coercion? Clearly not: while states seek to maintain their monopoly of legitimate violence by suppressing other users of violence (except in some cases where individuals or corporations may be licensed to use violence, for example in selfdefense), there is no way in which they would either choose to suppress the non-state use of intelligence nor, in the unlikely event that they did (as, perhaps in a totalitarian regime), could they be entirely successful. Even if states have higher capacity, they will not seek to suppress non-state intelligence that deploys symbolic or material power. For example, corporations' interests are central to the health of liberal capitalism, its fiscal base and national wealth and therefore companies need no license to 'do' intelligence; indeed, governments assist by providing them with (mainly open source) information that pertains equally to state and corporate interests. There is a separate normative question as to what extent states should regulate corporate intelligence, to which we shall return.

\footnotetext{
${ }^{20}$ Max Weber, Political Writings, ed.. Lassman and Speirs (Cambridge: Cambridge University Press, 1994), 310-11.

21 Amitai Etzioni, A Comparative Analysis of Complex Organisations: on power, involvement and their correlates (New York: Free Press, 1961).

22 Warner, Intelligence as Risk Shifting, 20.
} 
The lack of any intelligence monopoly may seem obvious but must be examined in order to understand the possibility for a democratic intelligence. First, the state in many places 'is not the most decisive working unit in intelligence studies. ${ }^{23}$ Though written a quarter century ago, this is probably even more the case now. In the post Cold War world of multiple asymmetric conflicts and questionable state capacities, the role of 'sovereignties' has become ever greater. Even in the conflicts involving major states such as Afghanistan and Iraq, as we have seen, the intelligence role of corporations and ethnic, tribal or clan militias has been significant. It is precisely the fact of para-state control in certain conflict areas that is the cause and/or symptomatic of low state capacity. This is most especially so in border areas defined in terms of territory and/or 'marginal' populations, by reason of social exclusion or drug use. ${ }^{24}$

\section{Democratic Intelligence}

Looking historically at the development of intelligence capacities in the three sectors, it is clear that pre-state 'sovereignties' came first. Writers such as Sun Tzu in about the fourth century BC and Kautilya, possibly in the same era or several hundred years later, identified the significance of surveillance and intelligence to rule in ancient kingdoms. Both identified the importance of secret agents, the use of covert action, the dangers of subversion and the role of counter intelligence. ${ }^{25}$ Corporations in the modern rather than medieval sense arrived with industrialization and the rise in capitalism while recognizable state structures followed in the mid- to late nineteenth century.

Deploying Charles Tilly's work, we can identify two conditions for democratic intelligence: state capacity and the '...the extent to which the regime features broad, equal, protected, binding consultation of citizens with respect to state actions. ${ }^{26}$ For some writers, capacity and the legitimacy derived from respecting rights are seen as inseparable, for example,

\footnotetext{
'democracies are political systems comprising institutions that translate citizens' preferences into policy, have effective states that act to protect and deepen democratic rights, and count on a strong participatory and critical civil society. ${ }^{27}$
}

Fukuyama similarly doubts that legitimacy can be separated from capacity but, for the purposes of the present argument, it is preferable to examine capacity and legitimacy as independent variables. ${ }^{28}$ Tilly argues that the democratization process is enhanced by three main changes in public politics: the integration of interpersonal trust networks; the insulation of 'categorical inequality'; and a reduction in the significance of autonomous power centers. Equally, the reverse of these processes may induce de-democratization. ${ }^{29}$

'Trust networks are ramified interpersonal connections, consisting mainly of strong ties, within which people set valued, consequential, long-term resources and enterprises at risk to the malfeasance, mistakes, or failures of others. ${ }^{30}$

${ }^{23}$ Adda Bozeman, "Political Intelligence in non-Western societies: suggestions for comparative research," in Comparing Foreign intelligence, ed. Roy Godson (Pergamon-Brasseys, 1988), 135.

${ }_{24}$ E.g. Ed Vulliamy, Amexica: war along the borderline (London: The Bodley Head, 2010).

${ }_{25}$ Samuel Griffith, Sun Tzu: The Art of War (London: Oxford University Press, 1963); L.N. Rangarajan, ed., Kautilya: The Arthashastra (New Delhi: Penguin, 1992), 462-504.

${ }^{26}$ Charles Tilly, Democracy (Cambridge: Cambridge University Press, 2007), 34.

27 Jean Grugel, Democratization: a critical introduction (Basingstoke: Palgrave, 2002), 36.

${ }_{28}$ F. Fukuyama, State-Building: governance and world order in the $21^{\text {st }}$ century (Ithaca, Cornell UP, 2004), 26.

29 Tilly, Democracy, 74-77.

${ }^{30}$ Ibid., 74. 
Examples such as trading diasporas, religious groups, clans and criminal organizations tend to shield themselves from involvement in political regimes but if they remain segregated it is an obstacle to democratization. If they integrate with regimes and motivate members to engage in mutually binding consultation with the state then democratization is possible. With respect to intelligence in particular, this can be seen by the extent to which members of trust networks come to rely on the state rather than their own resources to provide for security and, indeed, show willingness to volunteer relevant information to state agents. The significance of this can be easily illustrated by pointing to times/places where the condition was absent: 'no-go' areas to police in parts of Belfast and Londonderry in Northern Ireland during the 'Troubles', Native American 'reservations' - especially those crossing US borders with Canada or Mexico, and members of criminal organizations such as Mafia in which an 'oath of silence' is a key element.

'Categorical inequality' refers to the

'organization of social life around boundaries separating whole sets of people who differ
collectively in their life chances, as is commonly the case with categories of gender, race,
caste, ethnicity, nationality, and religion and is sometimes the case with categories of social
class. To the extent that such inequalities translate directly into categorical differences in
political rights and obligations, democracy remains impossible.' ${ }^{31}$

Intelligence may become very significant in such a situation since the ruling group will require reassurance as to its position; indeed, the regime might come to resemble a counterintelligence state ${ }^{32}$ in which the sole purpose of intelligence is to protect the regime against internal opposition. BOSS and its successor National Intelligence Service in South Africa under apartheid was a prime example. Even where efforts have been made to insulate public politics from these categorical inequalities, for example, by adopting devices such as secret ballots, security officials may play a key role in dissuading voters from attending voting places.

Third, '(a)utonomous power centers operate outside the control of public politics and outside of regular citizen-state interactions. ${ }^{33}$ This includes all those interpersonal connections providing citizens with the means to alter or defend existing distributions of resources in their interest. Especially significant are those that may exist within the state, for example, armed forces or intelligence agencies, and inhibiting their autonomy to act in their sectional interest is a crucial aspect of democratization. Mechanisms by which this might come about include coalition formation between ruling classes and those previously excluded or co-optation of previously autonomous actors such as regional 'strongmen'.

Therefore, in order to assess to what extent states have capacity in the intelligence field, we need to identify the process by which state intelligence is established independently of non-state 'sovereignty' capacities. Or, to what extent and how does state intelligence replace pre-existing 'trust networks' and 'autonomous power centers'? This is an interesting historical question which has, as yet, received little if any attention. State intelligence services came into existence for three main reasons - to detect foreign threats and inform foreign policy, to support military operations and to detect threats to internal security. In other words, to carry out tasks quite distinct from those already being carried out by corporations and self-

\footnotetext{
31 Tilly, Democracy, 75 .

32 Cf. John Dziak, Chekisty: A History of the KGB (Lexington, MA.: Lexington Books, 1988).

33 Tilly, Democracy, 76.
} 
protecting sovereignties. In some cases, state intelligence will have rendered these redundant, for example, the British army and government slowly taking over intelligence in India from the East India Company. A general increase in state capacity and penetration throughout its territory will reduce the need for local sovereignties to act in their self-defense. However, this is a process that will never be complete: we have already pointed to the impossibility of a state monopoly of intelligence, therefore, the question becomes not whether the state can displace or incorporate them (á la Tilly) but whether the state can work out a non-competitive modus vivendi with them. This might occur through contracting, advice, consultation, division of labor, networking and so on. However, tracing the precise process by which state intelligence becomes an alternative or complementary to varieties of non-state intelligence is beyond the scope of this article which, instead, concentrates on the issue of democratization in the three sectors.

\section{Democratizing State Intelligence}

Many of the national 'democratizations' of intelligence in the past quarter century have been far less dramatic than envisaged by conquest or revolution but some have certainly involved domestic confrontation in the context of regime change. In Eastern Europe the offices of the Stasi in Leipzig were ransacked as the Berlin Wall fell and the Ceacescus were shot in Bucharest, signaling change in Romania. ${ }^{34}$ In the former Yugoslavia, Slovenia escaped the war and reformed peacefully, in Serbia and Croatia intelligence reform proceeded but unevenly after the end of the war in $1995 .{ }^{35}$ In Bosnia, reform of the intelligence architecture was embroiled in the overall political stagnation but a new national agency started work in 2004. ${ }^{36}$ Similarly, there were different patterns in Latin America as military regimes were replaced through the 1980s and 1990s but in all cases the process was less violent than their coming to power. ${ }^{37}$

The issues of trust networks and autonomous power centers clearly underlie the legislative attempts to reform intelligence in the wake of authoritarian regimes. Nobody trusts security or intelligence agencies in single-party or military regimes; even the leaders fear them and the proliferation of agencies often found under authoritarianism is the result of 'divide and rule' and the hope that agencies will spy on each other. Apart from leading to general paranoia, this is also hopelessly inefficient and wasteful. The reform process does not necessarily succeed in cutting the number of agencies - the 'securocrats' can be very persuasive as to the new regime's need for their specialist skills and information - but a minimal requirement is that the conditions for the development of trust are established. This requires legislation so that the structure of agencies and their mandate are established in law (rather than simply as a matter of executive decree). Intelligence agencies are distinguished from other government departments by the fact that they may gather information covertly in addition to open sources

${ }^{34}$ Williams and Deletant, 2001 compare change in the Czech Republic, Slovakia and Romania. K. Williams and D. Deletant, Security Intelligence Services in New Democracies: The Czech Republic, Slovakia and Romania (Basingstoke: Palgrave, 2001).

${ }_{35}$ Anja Ebnöther, Philipp Fluri and Jurekovic, Security Sector Governance in the Western Balkans: self-assessment studies on defence, intelligence, police and border management reform (Geneva: DCAF, 2007).

${ }^{36}$ Kalman Kocsis, "Bosnia and Herzegovina," in PSI Handbook of Global Security and Intelligence, National Approaches, volume 2, ed. Stuart Farson et al. (Westport, CT: Praeger Security International, 2008), 439-55.

${ }_{37}$ Priscila Antunes, "Establishing Democratic Control of Intelligence in Argentina," in Reforming Intelligence: obstacles to democratic control and effectiveness, ed. Thomas Bruneau and Steven Boraz (Austin: University of Texas Press, 2007), 195218; Marco Cepik, "Structural Change and Democratic Control of intelligence in Brazil,' in Reforming Intelligence: obstacles to democratic control and effectiveness, ed. Thomas Bruneau and Steven Boraz (Austin: University of Texas Press, 2007), 149-69. 
and the process, by which these special powers can be authorized, for example, by a judge or minister, must be spelt out.

The precise relationship between agencies and the political regime is normally shrouded in secrecy within authoritarian regimes, for example, are security officials simply the servants of the Party or the Generals or do they constitute a 'state within the state'? Within a democratic structure the object is to avoid either extreme of agencies being a rule unto themselves (an 'autonomous power centre') or simply the handmaiden of the party in power. It was common in the 1990s democratization in Eastern Europe for opposition politicians to assume that the agencies were still being used against them at election times, and sometimes they were right! Therefore, the relationship between ministers and agencies must be made clear so that, on the one hand, the agencies are working to the agreed security priorities of the government, not their own, while, on the other, there are procedures to enable a Director to blow the whistle on any attempts to use her agency for improper or partisan purposes.

After the fact of legislation itself, the single most significant measure required in order to generate a new trust network is the oversight role of Parliaments and other external bodies who might challenge the intelligence agencies on behalf of citizens. Apart from passing the legislation itself, parliaments have a crucial role in budgetary control: one of the main enablers of security and intelligence abuse is the existence of 'off-the-books' budgeting and the deployment of secret state funding. In some cases, this problem is reinforced by the agencies supplementing their funds - and autonomy - by running their own businesses, for example the Indonesian National Intelligence Agency (BIN) runs its own newspaper. It has become the norm now for parliament also to establish some committee for the oversight of security and intelligence agencies; often this is a joint committee of a bicameral legislature. The details of the mandate and powers to access information are crucial in determining the potential influence of such a committee but whether or not it has a real rather than purely symbolic impact will depend on the political will of the membership to do a good job and whether they can actually develop a relationship of trust with the agencies. ${ }^{38}$

\section{The Corporate Sector}

First, we must note that very little has been written about the privatization of intelligence compared with military and security services more generally. Here I am not addressing corporate use of business or competitive intelligence but the involvement of corporate actors in direct security issues. What we do know concerns mainly the U.S. where the rise of the corporate intelligence sector has been mapped by Tim Shorrock: by 2006 , about $70 \%$ of the estimated $\$ 60$ billion the government spent on foreign and domestic intelligence was outsourced to contractors. ${ }^{39} \mathrm{He}$ identifies four main periods of development: the privatization revolution that started during the Reagan administration but which reached fruition under Clinton; the leap in defense outsourcing in the late 1990s; the surge in intelligence spending negotiated by Director of Central Intelligence (DCI) George Tenet at the turn of the century after a decade of cuts; and the post-9/11 expansion. Technological innovation was a key element in this as commercial developments in encryption; IT etc. outpaced government innovations and coincided with the downsizing post 1991. Thus, by the turn of the century, Shorrock argues, the institutional memory of the U.S. Intelligence Community resided in the

\footnotetext{
38 Born and Leigh, 2005, provide a detailed overview of 'best practice'. Born and Leigh, Making Intelligence Accountable.

39 Tim Shorrock, Spies for Hire: the secret world of intelligence outsourcing (New York: Simon and Schuster, 2008 ), 6.
} 
private sector. Contracting soared in the aftermath of 9/11 and it was only in 2005-06 that USG started concerted hiring at agencies themselves. ${ }^{40}$

The main structural reason for the significance of the corporate sector since $9 / 11$ and the new emphasis on 'homeland security' was the simple fact that $90 \%$ of communications, energy and transportation networks is in the private sector and required public-private partnerships. Just after $9 / 11$ the Senate Select Committee on Intelligence called for a 'symbiotic relationship between the Intelligence Community and the private sector, ${ }^{41}$ and this ideology of the Intelligence-Industrial Complex was born from a blend of patriotism, national chauvinism, fear of the unknown and old-fashioned war-profiteering. ${ }^{42}$

A key figure was Kenneth Minihan, former director of NSA and DIA, who, together with Jim Woolsey, former CIA director, created the Paladin Capital Group in 2002 as the first private equity fund to invest exclusively in companies making products for the homeland security and intelligence markets. Minihan argued that economic globalization and the communications revolution meant CIA/NSA etc. could no longer act in a vacuum; industry and government must join forces to defeat the nation's adversaries so that contractors were now inextricably tied to the success of operations, presenting opportunities to create technologies that government can use "with all the complexities that exist in merging the interests of the private and public sector in the intelligence apparatus. ${ }^{43}$ What is striking about this is, of course, that public-private contracting and partnership are facts of any liberal capitalist economy, but the merging or symbiosis of interests in security and intelligence apparatus takes us into the realms of a corporatist state in which government takes place through private corporations. This raises profound issues about the nature of intelligence governance in the U.S.; bearing in mind the 'neglected stepchild' of congressional oversight, ${ }^{44}$ de-democratization is apparently underway.

Beyond oversight of the state sector, almost nowhere has there been any effort to examine the corporate sector. Chesterman identifies three main challenges to oversight of corporate intelligence: secrecy, the different incentives for private compared with public employees and the uncertainty as to what functions should be regarded as 'inherently governmental' and thus unsuitable for outsourcing. It was only in the U.S. Intelligence Authorization Act for Fiscal Year 2008 that, for the first time, the Office of Director of National Intelligence (ODNI, successor to DCI) would be required to provide the intelligence committees with detailed reports on the use of contractors and the accountability mechanisms governing their performance but the legislation was vetoed by President Bush. However, even these congressional efforts were led by just a few members of Congress; for others the intelligence budget was just another chance for 'pork barrel' politics in the face of massive lobbying from contractors. ${ }^{45}$ So far there remains a good deal of ambiguity around the attempt to determine which intelligence functions are 'inherently governmental', especially when even those that are can still be outsourced if it amounts to the 'implementation' rather than 'control' of policy. ${ }^{46}$

${ }^{40}$ Shorrock, Spies for Hire, 81-114.

${ }^{41}$ Simon Chesterman, “'We Can’t Spy...If We Can’t Buy!': the privatization of intelligence and the limits of outsourcing 'inherently governmental functions'," European Journal of International Law 19, no.5 (2008): 1056.

42 Shorrock, Spies for Hire, 357.

43 Ibid., 363.

${ }^{44}$ Loch Johnson, "The Church Committee Investigation of 1975 and the Evolution of Modern Intelligence Accountability," Intelligence and National Security 23, no.2 (2008): 220.

${ }_{45}$ Chesterman, "We Can't Spy", 1066-1067; Shorrock, Spies for Hire, 366-372.

${ }^{46}$ Chesterman, "We Can't Spy", 1069-1073. 
Beyond the political sphere, there are a number of other mechanisms with potential for overseeing the corporate sphere such as the law, contract conditions, auditing, and public reputations. For example, there is some potential for the development of 'corporate social responsibility' in private security and military companies. ${ }^{47}$ The idea of increasing competition between public and private providers of military goods and services and publishing relevant data so citizens can make informed choices is at the heart of neoliberal security governance. Examples include free trade in military goods and services among NATO and EU members through privatization of national defense companies and harmonization of standards, and mutual recognition of national licenses for private security and policing services. There is also a role for private standard-setting and self-regulation, with a role for industry associations and reinforced by market pressures. The state's role is to establish conditions to support private industry standards and to be a responsible consumer, buying from the best suppliers. ${ }^{48}$

But there are a number of reasons as to why these market and reputation-driven checks may falter in practice. First, considerations of commercial confidentiality combined with national security mean that citizens just will not know just what is being contracted and at what cost. Second, however strong the identification of contractors with government policy, the fact remains that their firms exist to make profit, not serve the public interest. Given the growing symbiosis noted above, there is a clear danger of public policy being subordinated to profitability. Third, market disciplines are much reduced when, as in security contracting, there may be only a few firms with the relevant capacity. Even where there are trade associations, their impact may be to raise barriers to entry to new firms and thus retain oligopolistic relations with government. Thus, if security contracting is characterized more accurately as 'corporatism' than a marketplace, more profound questions of governance are raised: the more autonomous the power of the Intelligence Industrial complex, the more democracy is reduced.

We simply do not know the extent to which other countries have followed the same route as the U.S. On the face of it, the UK would be favorite since it has followed a similar path of post Cold War downsizing in the context of the information revolution and a neoliberal governing ideology. The UK intelligence community will have a similar dependence on the corporate sector for hardware and software but there is less evidence of the wholesale involvement of the corporate sector in tasks such as collection, analysis and, more controversially, interrogation, as happened in the U.S. However, the continued significance of technological change in the context of states facing the budgetary implications of the financial crisis that started in 2008 does not suggest any likely diminution in the corporate role in security intelligence.

\section{Democratizing 'Sovereignties' - a Contradiction in Terms?}

Alongside its directory of state intelligence agencies, the American Federation of Scientists Intelligence Resources Program lists over 300 'para-states' including national liberation movements, drug cartels, ethnic militias and terrorist groups. ${ }^{49}$ As such, it might appear

\footnotetext{
47 Christopher Kinsey, "Private security companies and corporate social responsibility," in Private Military and Security Companies: ethics, policies and civil-military relations, ed. Andrew Alexander, Deane-Peter Baker, Marina Caparini (London: Routledge, 2008), 70-86.

48 Elke Krahmann, States, Citizens and the Privatization of Security (Cambridge: Cambridge UP, 2010), $254-256$.

49 "Liberation Movements, Terrorist Organizations, Substance Cartels, and Other Para-State Entities," Federation of American Scientists, accessed December 10, 2010, http://fas.org/blogs/secrecy/2010/03/12_frus_volumes/10/
} 
slightly absurd to ponder the potential for democratization among such groups. Most of the time, states will be concerned to try to contain if not suppress and obliterate these groups and some are quite short-lived. Yet we need to think about why some of them have a longer history. This may be because, as a criminal organization, they are supplying products in a market where demand is very strong. If this is coupled by supply being concentrated in areas where states hardly penetrate, then it may well be that the organization constitutes the main employer and supplier of 'security' and social services in that area. In other words, the longevity of such an organization will be accounted for to some extent by support from local populations which, while not confirmed by elections or any such device, will be strong enough to resist information gathering attempts by state agents. This may not constitute 'legitimacy' in the Weberian sense of the term but popular acquiescence is a factor that must be taken into account.

In other cases, the situation will be complicated by the fact that the state, though opposing the organization in rhetoric, will actually seek an accommodation based on a realization that, realistically, it cannot suppress it and, in the meantime, is better off negotiating a relatively peaceful, albeit possibly temporary situation in return for a cessation of attacks on state officials. In general terms, the coca-growing areas of Colombia and poppy-growing areas of Afghanistan have 'enjoyed' such a situation from time to time.

National liberation movements, especially where they dominate some part of a state's territory, provide an even better example of the competitive nature of legitimacy; indeed, the contest over legitimacy is the very essence of nationalist insurgencies. If they are successful, then the interesting situation arises of the insurgents' intelligence operatives becoming the official state agents or, in the case of peaceful regime change, being integrated into the state agencies who were previously their opponents. This was the situation in South Africa where the government's National Intelligence Service and the Department of Intelligence and Security of the ANC's armed wing Umkhonto we Sizwe (MK), having fought each other for years, were then crucial to the negotiations in the early 1990s and both provided personnel to the new National Intelligence Agency in $1995 .{ }^{50}$

We must beware that the further notions of 'democratization' travel from their European and North American origins, the less likely it is that they will take root in the ways originally envisaged. There is too often a tendency in the West to equate (more or less) fair elections with democracy when, in fact, it is at best a procedural or 'pseudo democracy' ${ }^{51}$ Where states, for whatever reason, lack the capacity to provide protection to citizens, and even more where the state itself is perceived as predatory, then the existence of security and intelligence groups based on locality, ethnicity, or clan may actually enjoy a legitimacy that cannot simply be dismissed. For example, a recent study of Indonesia concludes:

\footnotetext{
'...the nature of state and society in Indonesia is such that conventional notions of democratisation in terms of the democratic control of state agencies is inadequate to deal with the complexities of Indonesia in which the legitimacy or otherwise of many corporate and 'community' organisations performing intelligence functions and security roles must also be considered.' 52
}

${ }^{50}$ O'Brien, "South Africa".

${ }^{51}$ Larry Diamond, Developing Democracy: Towards Consolidation (Baltimore: John Hopkins University Press, 1999), 15.

${ }_{52}$ Peter Gill and Lee Wilson, "Intelligence and Security Sector Reform in Indonesia," in Intelligence Elsewhere: spies and espionage outside the Anglosphere, ed. Philip Davies and Kristian Gustafson (Washington DC: Georgetown University Press, 2013), 


\section{Intelligence Networks and Accountability}

Structures designed for single sectors such as state hierarchies will be inadequate for multisectoral governing networks. ${ }^{53}$ Although this issue has been addressed in various policy fields, we are only now starting to think through the implications for intelligence. All we can confidently predict is that the task will be extremely challenging! This final section of the article seeks to identify some areas of possible development in order to develop much needed oversight of intelligence networks that have developed both within and between nations, levels and sectors.

For example, national oversight within the state sector should be functional, not institutional. Failing that, parliamentary or other overseers must develop their own networks - if there is more than one oversight body within the state, then they should use 'statutory gateways' enabling them to cooperate on investigations, such as suggested in the report of the inquiry into the Maher Arar case in Canada. ${ }^{54}$ Between states, some limited mechanisms for discussion are already in existence, for example, the biennial International Intelligence Review Agency Conferences. Currently, these are largely closed events during which participants share ideas of best practice; that should be continued but it would be useful if additional time could be spent in discussion with other interested parties, including specialist journalists, academics and representatives of civil society. Within Europe there are some existing transnational bodies, e.g. European Parliament (EP) and Council of Europe (CoE) which both examined extraordinary rendition. The advantage of these bodies is that they transcend the national but they have no authority over national governments to compel disclosure. For example, carrying out the $\mathrm{CoE}$ study into rendition, Marty said:

\footnotetext{
We must condemn the attitude of the many countries that did not deem it necessary to reply to the questionnaire we sent them through their national delegations. Similarly, NATO has never replied to our correspondence..$^{55}$
}

There are some supra national European bodies with intelligence functions - Europol, Sitcen, Frontex - and the European Parliament seeks to increase its oversight of them but almost all significant intelligence sharing and cooperation occurs bi-laterally and beyond the gaze of even supra national bodies.

The law has a greater role now in governing intelligence than 25 years ago, but it 'empowers' as well as 'limits' agencies. Yet the development of rules by national and supranational bodies, their application and judicial oversight by, for example, the European Court of Human Rights (ECtHR) can make a contribution to the task of overseeing intelligence, especially regarding its propriety. It is also noteworthy that courts are now less deferential on security matters than even ten years ago - 23 Americans, mainly CIA officials, have been convicted in Italy for their part in the extraordinary rendition of Abu Omar in 2003 and face arrest if they travel to Europe. However, the courts in Germany have upheld the Government's decision not to seek the extradition of CIA agents allegedly involved in the rendition of Khaled el-Masri, despite the issue of an arrest warrant. ${ }^{56}$ Although the informality of networks that is prized by

53 E.g. Thorsten Benner et al., "Multisectoral Networks in Global Governance: towards a pluralistic system of accountability," in Global governance and Public Accountability, ed. David Held and Mathias Koenig-Archibugi (Oxford: Blackwell, 2005).

54 "Commission of Inquiry into the Actions of Canadian Officials in Relation to Maher Arar," in A New Review Mechanism for the RCMP"s National Security Activities (Ottawa: Minister of Public Works and Government Services, 2006).

55 Dick Marty, "Alleged Secret Detentions and Unlawful Inter-State Transfers of Detainees Involving Council of Europe Member States: Second report," Parliamentary Assembly, Council of Europe, June 11, 2007, 20.

56 Eddy, "Court rejects el-Masri suit against German government," The Miami Herald, December 10, 2010. 
practitioners reduces the impact of law, Richard Aldrich argues that the law has still had more impact in terms of intelligence oversight since 9/11 than 'toothless' political mechanisms. ${ }^{57}$ However, while the law might occasionally have impact through cases brought before the courts, the vast majority of intelligence operations never do come to court. The law is little use for regular auditing and monitoring.

Since a common feature of covert action is that intelligence agencies use 'grey' financial channels, agencies should be required to inform their oversight committees of financial incomings and outgoings with other agencies and the corporate sector in connection with operations, training, equipment etc. Much intelligence sharing takes place electronically and there is potential for built-in auditing that can be accessed by overseers. For the foreseeable future, however, institutional forms of oversight of intelligence networks will remain largely undeveloped and, as we saw in the case of rendition, it is most likely to occur as a result of informal coalitions of parliamentarians, lawyers, researchers, journalists and those working in civil society organizations. All of these can contribute to 'regulation through revelation' ${ }^{58}$ Indeed, in an age of Wikileaks, Cryptome et al, we should make a virtue of necessity and encourage all the various forms of oversight as they emerge in both official and unofficial contexts.

\section{Conclusion}

There are major problems with state governance of intelligence: the context of secrecy may provide the cover for authoritarianism and corruption while fragmentation between agencies may compound a lack of effectiveness in informing security policies. But, compared with the other sectors, only the state can secure adequate resources, provide for reasoned debate and protect the general public interest in matters of security intelligence. ${ }^{59}$ Therefore, the process of democratizing intelligence requires the development of state capacity not only in developing intelligence itself but also for the regulation of private companies and suppression of uncivil sovereignties. As we have seen, the cooperative and competitive interaction between these sectors can be very complex and challenges any simple notion of state governance of intelligence but the search for democratic accountability within what sometimes appear to be neo medieval corporatist structures is crucial to the task of establishing intelligence that is more progressive than repressive. ${ }^{60}$

\section{Bibliography}

“Awakening Movement in Iraq.” New York Times, December 21, 2010. http://topics.nytimes.com/top/news/ international/countriesandterritories/iraq/awakening_movement/index.html.

"Commission of Inquiry into the Actions of Canadian Officials in Relation to Maher Arar." In A New Review Mechanism for the RCMP"s National Security Activities. Ottawa: Minister of Public Works and Government Services, 2006.

\footnotetext{
57 Richard Aldrich, "Regulation by Revelation? Intelligence, Transparency and the Media," in Known Knowns: British and American Intelligence and the Media, ed. R. Dover and M. Goodman (New York: Columbia University Press, 2009), 134.

58 Richard Aldrich, "US-European Intelligence Cooperation on Counter-Terrorism: Low Politics and Compulsion," British Journal of Politics and International Relations 11, no.1 (2009): 122-39.

${ }_{59}$ Cf. Ian Loader and Neil Walker, Civilizing Security (Cambridge: Cambridge University Press, 2007).

${ }^{60}$ Cf. Philip Cerny, "Globalisation, governance and complexity," in Globalization and Governance, ed. Asseem Prakash and Jeffrey Hart (London: Routledge, 1999), 188-212.
} 
Aldrich, Richard. "Regulation by Revelation? Intelligence, Transparency and the Media." In Known Knowns: British and American Intelligence and the Media, edited by R. Dover and M. Goodman. New York: Columbia University Press, 2009.

Aldrich, Richard. "US-European Intelligence Cooperation on Counter-Terrorism: Low Politics and Compulsion." British Journal of Politics and International Relations 11, no.1 (2009): 122-39

Antunes, Priscila. "Establishing Democratic Control of Intelligence in Argentina." In Reforming Intelligence: obstacles to democratic control and effectiveness, edited by Thomas Bruneau and Steven Boraz, 195-218. Austin: University of Texas Press, 2007.

Avant, Deborah. The Market for Force: the consequences of privatizing security. Cambridge: Cambridge UP, 2005.

Benner, Thorsten. Wolfgang Reinicke and Jan Witte. "Multisectoral Networks in Global Governance: towards a pluralistic system of accountability." In Global governance and Public Accountability, edited by David Held and Mathias Koenig-Archibugi, 67-86.Oxford: Blackwell, 2005.

Born Hans and Ian Leigh. Making Intelligence Accountable: legal standards and best practice for oversight of intelligence agencies. Oslo: Publishing House of Parliament of Norway, 2005.

Bozeman, Adda. "Political Intelligence in non-Western societies: suggestions for comparative research." In Comparing Foreign Intelligence, edited by Roy Godson. Pergamon-Brasseys, 1988.

Bruneau, Thomas and Steven Boraz. Reforming Intelligence: obstacles to democratic control and effectiveness. Austin: University of Texas Press,2007.

Campbell, Bruce and Arthur Brenner, ed. Death Squads in Global Perspective: murder with deniability. Basingstoke: Macmillan, 2000.

Cepik, Marco. "Structural Change and Democratic Control of intelligence in Brazil." In Reforming Intelligence: obstacles to democratic control and effectiveness, edited by Thomas Bruneau and Steven Boraz, 149-69. Austin: University of Texas Press, 2007.

Cerny, Philip. "Globalisation, governance and complexity." In Globalization and Governance, edited by Asseem Prakash and Jeffrey Hart, 188-212. London: Routledge, 1999.

Chesterman, Simon. "'We Can't Spy...If We Can't Buy!': the privatization of intelligence and the limits of outsourcing 'inherently governmental functions'.” European Journal of International Law 19, no.5 (2008): 1055-74.

de Jong, Ben, Wies Platje and Robert Steele. Peacekeeping Intelligence: emerging concepts for the future. Oakton, VA: OSS International, 2003.

Diamond Larry. Developing Democracy: Towards Consolidation. Baltimore: John Hopkins University Press, 1999.

Dombrowski, Kenneth. "Transforming Intelligence in South Africa." In Reforming Intelligence: obstacles to democratic control and effectiveness, edited by Thomas Bruneau and Steven Boraz, 241-68. Austin: University of Texas Press, 2007.

Dziak John. Chekisty: A History of the KGB. Lexington, MA.: Lexington Books, 1988.

Ebnöther, Anja, Philipp Fluri and Jurekovic. Security Sector Governance in the Western Balkans: self-assessment studies on defence, intelligence, police and border management reform. Geneva: DCAF, 2007.

Eddy. "Court rejects el-Masri suit against German government." The Miami Herald, December 10, 2010.

Etzioni, Amitai. A Comparative Analysis of Complex Organisations: on power, involvement and their correlates. New York: Free Press, 1961.

Farson, Stuart, Peter Gill, Mark Phythian and Shlomo Shpiro. PSI Handbook of Global Security and Intelligence, National Approaches, 2 volumes. Westport, CT: Praeger Security International, 2008.

Federation of American Scientists. "Liberation Movements, Terrorist Organizations, Substance Cartels, and Other Para-State Entities.” Accessed December 10, 2010. http://fas.org/blogs/secrecy/2010/03/12_frus_volumes/10/

Fukuyama, F. State-Building: governance and world order in the $21^{\text {st }}$ century. Ithaca, Cornell UP, 2004.

Gill, Peter and Lee Wilson. "Intelligence and Security Sector Reform in Indonesia." In Intelligence Elsewhere: spies and espionage outside the Anglosphere, edited by Philip Davies and Kristian Gustafson, 157-79. Washington DC: Georgetown University Press, 2013.

Gill, Peter. "Inquiring into Dirty Wars: a "huge smokescreen of humbug"?" In Commissions of Inquiry and National Security, edited by Stuart Farson and Mark Phythian. Santa Barbara: ABC-Clio, 2011.

Gill, Peter. “Theories of Intelligence: where are we, where should we go and how might we proceed?" In Intelligence Theory: key questions and debates, edited by Peter Gill, Stephen Marrin and Mark Phythian, 208-26. London: 
Routledge, 2009.

Griffith, Samuel. Sun Tzu: The Art of War. London: Oxford University Press, 1963.

Grugel Jean. Democratization: a critical introduction, Basingstoke: Palgrave, 2002.

Johnson, Loch. "The Church Committee Investigation of 1975 and the Evolution of Modern Intelligence Accountability." Intelligence and National Security 23, no.2 (2008): 198-225.

Kahaner, Larry. Competitive Intelligence: how to gather, analyze, and use information to move your business to the top, New York: Touchstone, 1996.

Kinsey, Christopher. "Private security companies and corporate social responsibility." In Private Military and Security Companies: ethics, policies and civil-military relations, edited by Andrew Alexander, Deane-Peter Baker, Marina Caparini, 70-86. London: Routledge, 2008.

Kocsis, Kalman. "Bosnia and Herzegovina." In PSI Handbook of Global Security and Intelligence, National Approaches, volume 2, edited by Stuart Farson et al., 439-55. Westport, CT: Praeger Security International, 2008.

Krahmann, Elke. States, Citizens and the Privatization of Security. Cambridge: Cambridge UP, 2010.

Kurban, Dilek. "The Village Guard System as a "Security" Policy." In Security Sector and Democratic Oversight, edited by Ali Bayramoğlu and Ahmet Insel, 203-10. Istanbul: TESEV, 2010.

Loader, Ian and Neil Walker. Civilizing Security. Cambridge: Cambridge University Press, 2007.

Marty, Dick. "Alleged Secret Detentions and Unlawful Inter-State Transfers of Detainees Involving Council of Europe Member States: Second Report.” Parliamentary Assembly, Council of Europe, June 11, 2007.

Mason, Rowena and Richard Blackden. "Shell to pay \$48m Nigrian bribe fine." The Telegraph, November 4, 2010.

Norwitz, Jeffrey. Pirates, Terrorists, and Warlords: the history, influence, and future of armed groups around the world. New York: Skyhorse Publishing, 2009.

O"Brien, Kevin. "South Africa." In PSI Handbook of Global Security and Intelligence, National Approaches, volume 2, edited by Stuart Farson et al., 619-50. Westport, CT: Praeger Security International, 2008.

Ranelagh, John. The Agency: the rise and decline of the CIA. New York: Simonand Schuster, 1987.

Rangarajan, L.N. ed. Kautilya: The Arthashastra. New Delhi: Penguin, 1992.

Richelson, Jeffrey and Desmond Ball. The Ties that Bind. Boston: Unwin Hyman, 1990.

Scahill, Jeremy. Blackwater: the rise of the world"s most powerful mercenary army. London: Serpent"s tail, 2007.

Scott, Len and Peter Jackson. "The Study of Intelligence in Theory and Practice." Intelligence and National Security 19, no.2 (2004): 139-69.

Sharp, Seena. Competitive Intelligence Advantage: how to minimize risk, avoid surprises and grow your business in a changing world. Hoboken, NJ: John Wiley and Sons, 2009.

Shorrock, Tim. Spies for Hire: the secret world of intelligence outsourcing. New York: Simon and Schuster, 2008.

Shpiro, Shlomo. "Intelligence, peacekeeping and Peacemaking in the Middle East." In Peacekeeping Intelligence: emerging concepts for the future, de Jong et al., 101-14. Oakton, VA: OSS International, 2003.

Singer, Peter. Corporate Warriors: the rise of the privatized military industry. Ithaca: Cornell University Press, 2003.

Tilly, Charles. Democracy, Cambridge: Cambridge University Press, 2007.

Vulliamy, Ed. Amexica: war along the borderline. London: The Bodley Head, 2010.

Warner, Michael. "Intelligence as Risk Shifting." In Intelligence Theory: key questions and debates, edited by Gill, et al., 16-32. London: Routledge, 2009.

Weber, Max. Political Writings, edited by Lassman and Speirs. Cambridge: Cambridge University Press, 1994.

Wikileaks. "Shell Md Discusses The Status Of The Proposed Petroleum." http://wikileaks.ch/ cable/2009/10/09ABUJA1907.html.

Williams K. and Deletant D. Security Intelligence Services in New Democracies: The Czech Republic, Slovakia and Romania. Basingstoke: Palgrave, 2001. 